

\title{
Qualidade das notícias em ciência e medicina: a imprensa na medicina regenerativa no Brasil
}

\author{
News quality in science and medicine: the press \\ on regenerative medicine in Brazil
}

Liliana Acero*

\section{Resumo}

Os meios de comunicação de massa funcionam como uma ponte entre a ciência, a medicina e o público. Discute-se a qualidade dos relatos recentes da imprensana medicina regenerativa em dois jornais nacionais, a Folha de São Paulo e O Globo, e no contexto do jornalismo internacional. Aplicamse a aproximação teórica da Ciência, Tecnologia e Sociedade e o estudo sociológico qualitativo dos enquadramentos, para compreender o impacto da imprensa na saúde coletiva. Estudam-se os dispositivos textuais nos relatos - metáforas, exemplos, frases de efeito e representações - e os elementos de raciocínio - origens, causas/efeitos e apelo a princípios. Dentro de uma escassez geral de matérias, salientam-se dois enquadramentos principais: o científico e o social, que refletem deficiências nas histórias, um otimismo exagerado no progresso nacional e sua legitimação em fontes internacionais. Essa situação contribui a induzir vieses no entendimento público e o desenvolvimento de falsas expectativas sobre as terapias celulares.

Palavras-chave: medicina regenerativa; meios de comunicação de massa; saúde coletiva; terapia celular; imprensa.

\begin{abstract}
Mass media acts as a bridge between science, medicine and the public. Quality of recent press reports on regenerative medicine within two national newspapers, Folha de São Paulo and O Globo, are discussed in the context of international journalism. The theoretical approach to Science, Technology and Society and the sociological qualitative study of framings are used to understand the impact of the press on collective health. Textual devices in news reports - metaphors, examples, catch-phrases and representations - and reasoning elements - origins, causes/effects and appeal to principles are studied. Within a general scarcity of news on the topic, two principal framings stand out: the scientific one and the social. These reflect story deficiencies, an exaggerated optimism about national progress and a search for legitimation through international sources. This can contribute to induce biases in public understanding as well as the development of false expectationsin the phase of cell-therapy application.
\end{abstract}

Keywords: regenerative medicine; mass media; cell and tissue-based therapy; collective health; the press. 


\section{INTRODUÇÃO}

O público acessa a mídia como fonte de informação privilegiada em ciência e medicina (Schäfer, 2012). A mídia coproduz as informaçôes de modo culturalmente específico, e estas se processam dentro das epistemologias cívicas: padróes de significados que os públicos utilizam para verificar dados e atuar na esfera social (Jasanoff, 2004). Mas o efeito dessa informação no entendimento públicoda ciência depende, em grande medida, de como ela é organizada e apresentada nas matérias.

Tem-se considerado que a cobertura dos meios de comunicação também influencia a legitimação da ciência e a medicina, e contribui para seu suporte público e financiamento (Kamenova, 2017). Como resultado, atualmente em muitos paísesse espera dos cientistas/médicos uma participação ativa na divulgação ou popularização da ciência. Uma política específica nessa direção e uma integração maior dos setores populares nos eventos e espaços científicos têm sido promovidas no Brasil econsideradas como iniciativas importantes no incentivo à participação social no desenvolvimento sustentável e à democratização da ciência (ex. CGEE,2019).

Nas últimas décadas, nos extensos debates sobre os modelos de transmissão da ciênciatem-se observado uma variedade de modalidades de analisar a comunicação em ciência.Dois modelos têm predominado. O convencional é baseado na teoria do 'déficit', que descreve as audiências leigas como desinformadas sobre os assuntos científicos e promove a educação e o treinamento de forma unidirecional, 'top down', para incentivar o entendimento público da ciência (ex. Collins; Evans, 2002).

O segundo modelo, mais relevante nos países europeus a partir da década dos 90s e inclusive promovido por políticas públicas do Estado, caracteriza o público como um participante ativo na comunicação em ciência e pretende incluir os conhecimentos leigos dentro da política pública (Irwin, 2006). Essas políticas de engajamento público 'bottom up', que procuram uma governança participativa ampla, foram elaboradas nos países avançados para conter as respostas negativas da sociedade civil a alguns dos desenvolvimentos em genética e biotecnologia em geral. Elas têm sido contraditoriamente instrumentais, contribuindo tanto para um aumento do engajamento público em direção à democratização da ciência e da medicina, quanto atuando como uma forma de legitimação adicional de interesses comerciais ou contribuindo para apromoção - para o público amplo - de um apoio consensual às biotecnologias da saúde (Irwin et. al., 2012).

O presente artigo busca avaliar a qualidade dos relatos da imprensa e, desse modo, oferecer uma contribuição ao entendimento do impacto eventual da mídia na saúde coletivae no entendimento público da ciência Para isso, 
realiza-se uma análise das notícias em uma área científica e médica de ponta: a medicina regenerativa (MR) no Brasil.

Aplicam-se no estudo, alguns conceitos da abordagem em Ciência, Tecnologia e Sociedade (CTS), com fins de pesquisar as seguintes perguntas:

- Qual é a qualidade da informação em MR reportada na imprensa?

- Quais são os sentidos dos padrôes persistentes observáveis nos relatos?

- Na cobertura, qual é o lugar que ocupam os assuntos sociais?

\section{A QUALIDADE NA INFORMAÇÃO JORNALİSTICA: O CONTEXTO}

$\mathrm{O}$ conteúdo da informação apresentada à população repercute em como ela visualiza os aportes da ciência e no modo como se desenvolve o entendimento público da ciência. Algumas das características apontadas como constituindo um bom jornalismo científico e médico incluem: a notoriedade das notícias selecionadas, a precisão nas informações apresentadas, o reconhecimento das limitaçóes dos jornalistas e das matérias e a capacidade de escrutínio crítico dos dados. O contexto em que se desenvolve a prática jornalística em nível global pode vir a influir também, de modo substantivo, na qualidade dos artigos produzidos.

Um outro fator dificulta a qualidade da informação acessada e entregue no jornalismo científico. A relação entre a ciência e o jornalismo tem sido, em nível histórico, pouco confortável; estabeleceu-se uma colaboração difícil entre cientistas, comunicadores da ciência e jornalismo (Peters, 2013). As linguagens, forma de trabalho e apresentação de dados dos três setores são bem diferentes e, às vezes, é difícil integrá-los.

$\mathrm{Na}$ Nova Zelândia, por exemplo, consultores em comunicação e cientistas acreditam que a qualidade da reportagem em ciências é pobre (Ashwell, 2016). Além disso, Bauer et al. (2013) apontam que dois terços dos jornalistas científicos americanos consideram seus colegas pouco críticos quando investigam as matérias. No Reino Unido, $71 \%$ do público acredita que a mídia assume uma atitude sensacionalista a respeito das ciências (Castell et al., 2014).

Um outro problema que afeta a qualidade das matérias se constitui na linguagem utilizada. Um estudo baseado em metacognição e desenvolvido por Bullock et al. (2019) provou que o uso do jargão aumenta as dificuldades das pessoas no processamento do conhecimento. Esse processo leva a um aumento da percepção de risco nas descobertas no público e a um menor suporte na adoção dos novos tratamentos. Além disso, alguns autores 
acharam que o público leigo tende a se irritar quando confrontado com conclusões de pesquisas incertas ou consequências adversas que incluem risco nas aplicaçôes terapêuticas (Peters, 2013). Esse tipo de reação pública poderia vir a interferir também na forma como os riscos e incertezas são reportados nos jornais.

Influi também significativamente na qualidade do conteúdo das matérias produzidas, a estrutura do trabalho no jornalismo como profissão. Este abrange as oportunidades de treinamento e especialização dos jornalistas, bem como, as suas condiçôes de trabalho. Em alguns países avançados, jornalistas da ciência têm percebido que existe, na atualidade, uma crise profissional (Bauer et al. 2013). No entanto, entre os fatores que intervêm significativamente nessa crise jornalística, enfatiza-seque a circulação de jornais teria sido atingida por um declínio global de leitores, devido ao aumento nas notícias televisivas e na cobertura onlinee que muitos jornais teriam se voltado às plataformas online para recuperar custos (McKinnon et al., 2017). Um fato comprovado éque, em nível internacional, os jornais têm reduzido o número de empregos (Chyi et al., 2012).

Como resultado, para os jornalistas que se mantêm na profissão, há considerável pressão para desenvolver mais matérias em períodos curtos de tempo (Bauer et al., 2013). O crescimento nas plataformas online também demanda que eles escrevam uma variedade de versóes diferentes das suas matérias. Uma pesquisa da Revista Nature, que entrevistou 493 jornalistas, encontrou que $59 \%$ acreditavam que o número de produtos por semana exigidos deles tem crescido nos últimos cinco anos (Brumfiel, 2009).

Neste contexto geral, os jornalistas científicos enfrentam desafios próprios para desempenhar seus papéis efetivamente. Por exemplo, o tempo necessário para checar a veracidade dos fatos, na frente de um crescente volume de produção científica, tem se reduzido significativamente (Murcott; Williams, 2013). Eles têm se voltado a escolher um número menor de fontes, de grande influência e que lhes merecem confiança, para filtrar os conteúdos das notícias (Ashwell, 2016; Besley; Tanner, 2011). Por exemplo, profissionais de relações públicas atuam como porta-vozes das instituições de pesquisa e começam a ser mais requeridos pelos jornalistas como fontes e filtros das informações (Schäfer, 2012). Eles são, em geral, profissionais da comunicação e não da ciência, e funcionam como porteiros (gatekeepers) no acesso às instituiçóes.

As várias mudanças apontadas, na profissão e no mercado tendem a diminuir a qualidade dos artigos publicados. A imprensa brasileira não é isenta das consequências das tendências globais apresentadas, como se reflete em alguns trabalhos de autores locais (ex. Massarani, 2013; Ramalho et al., 
2012). No Brasil, a escassez de treinamento especializado em jornalismo científico pode vir inclusive a acentuar o escasso escrutínio das informações publicadas.

\section{A MEDICINA REGENERATIVA NA IMPRENSA GLOBAL}

Os assuntos médicos de ponta - como, por exemplo, a medicina molecular - figuram entre os temas mais frequentemente presentes na cobertura mediática global (Elmet et. al., 2008). Mas eles cobrem um amplo espectro de disciplinas científicas: as pesquisas com células tronco, a terapia gênica e o sequenciamento dos genes no genoma humano. No caso específico da medicina regenerativa, há ainda bem menos trabalhos que explorem a comunicação na mídia. No caso do Brasil, não foi encontrado nenhum estudo publicado, segundo uma consulta nos arquivos do Catálogo de teses e dissertaçóes da CAPES; da Plataforma Lattes do CNPq e dos sítios web de algumas das revistas brasileiras centrais em saúde e afins ao assunto: Ciência e Saúde Coletiva, PHYSIS, Tecnologia e Sociedade, História, Ciência, Saúde - Manguinhos e RECIIS.

Muitos trabalhos de países avançados e no Brasil sobre a cobertura da mídia se desenvolveram em relação a debates específicos na área, como os das pesquisas com células tronco embrionárias (PCTE) e a clonagem terapêutica humana (Jurberg, et. al. 2009; Reis, 2008).

Entre os trabalhos mais relevantes ao presente estudo,encontram-se os de Nisbet; Brossard; Kroepsch (2008), os mais recentes de Kamenova; Caulfield (2015) e de Kamenova (2017) e, de modo tangencial, a análise de Lynch et. al. (2014) em relação à influência dos especialistas em relaçóes públicas na qualidade dos relatos da imprensa. O primeiro oferece um panorama quantitativo da cobertura mediática das pesquisas com células-tronco nas últimas quatro décadas e classifica a produção segundo estágios de desenvolvimento ligados a eventos importantes na área. Exploram-se as esferas políticas onde se desenvolvem as matérias, os níveis de drama nos textos apresentados e a utilização de analogias com histórias mais familiares ao público.

O estudo de Kamenova e Caulfield (2015) analisa a apresentação na imprensa entre 2010 e 2013, da nova fase translacional de resultados de pesquisa à clínica na MR e seu prognóstico futuro. Os autores encontram que o retrato mediático é otimista em $57,7 \%$ das matérias e acham resultados bastante semelhante entre EUA, Reino Unido e Canadá. A maioria dos textos reporta um tempo de chegada das terapias celulares (TC) ao mercado de entre 5-10 anos, ainda que uma proporção significativa as considere como disponíveis apenas em um futuro distante. Para os autores existe uma grande 
discrepância entre os reais desenvolvimentos científicos na área e a representação deles na mídia e na percepção pública. Dominam a imprensa as reportagens científicas sobre os ensaios clínicos em TC e há uma escassez de matérias associadas a questóes éticas, legais e sociais.

Como uma das fontes principais das notícias provém da comunidade científica, infere-se que os cientistas têm proporcionado aos jornalistas cenários irrealistas sobre os períodos de tempo para o lançamento das TC no mercado e, assim, têm contribuído para gerar falsas expectativas no público. Nessa linha, Kamenova (2017), analisando as notícias em PCTE em jornais de Canadá, EUA, Polônia, Reino Unido e França entre 1998 e 2013, explicou o papel ativo da mídia em validar principalmente as reivindicações científicas favoráveis sobre as descobertas na MR, em vez de desconstruir os temas, e os exageros ('bypes') das descobertas.

\section{ABORDAGEM CONCEITUAL E METODOLÓGICA}

O presente artigo baseia-se, de modo subjacente, em conceitos construtivistas centrais à área da Ciência, Tecnologia e Sociedade (CTS), como são a coprodução da ciência com a sociedade e as epistemologias cívicas ou formas tácitas de 'ficar sabendo', culturalmente específicas, que os cidadãos utilizam na esfera pública para verificar conhecimentos e demandar políticas públicas consequentes (Jasanoff, 2004, p.7). Essas abordagens conceituais ajudam a compreender como a imprensa contribui na formação do conhecimento dos 'públicos'.

Utiliza-se no presente artigo, um entendimento da transmissão da ciência como um processo de construção de sentido, ou seja, intimamente relacionada com significados e histórias culturais, seguindo autores vinculados principalmente a área de ciência, tecnologia e sociedade (CTS) (ex. Davies, et. al., 2019). A abordagem centra-se na dimensão experiencial e emotiva transmitida, que se sustenta na criação de significados e sentido e fundamenta-se na prática de contar histórias (Caulfield; Fahy, 2016). O processo de formação de sentido é baseado: na experiencia, narrativa/imagens, identidade e afeto, e pretende entender a qualidade da comunicação em contexto.

Essa perspectiva conecta a comunicação da ciência com outras preocupações humanas: o cuidado, a equidade, o respeito e a confiança, e permite pensar na estrutura da experiência também no sentido coletivo. Para Jasanoff; Kim (2015, p.4), por exemplo, a apresentação pública da ciência transmite imaginários sociais que são visóes de futuros desejáveis que se sustentam coletivamente, estabilizam-se institucionalmente, desenvolvemse publicamente e denotam suposições sobre as ordens sociais e políticas. 
Procura-se entender que aspecto é reforçado em situações específicas de contar histórias em ciência, por exemplo, ideias sobre a natureza da ciência, pressupostos sobre a sociedade ampla ou novas identidades (Halpern, 2012).

No artigo aprofunda-se, sobretudo, na abordagem sociológica ao estudo dos enquadramentos (frames/framing). Eles foram definidos inicialmente por Entman (1993, p.52) e implicam em uma seleção pelos jornalistas de alguns aspectos da realidade para enfatizá-los no texto comunicativo, de forma que se promova uma definição específica de um problema, uma determinada interpretação causal, uma avaliação ética ou moral e recomendações que melhorem ou solucionem a situação. Salientam-se nas notícias alguns aspectos do tema e outros se relegam, ocultam ou ficam sem visibilidade; e sugerem-se assim, atributos, julgamentos e decisóes dentro do relato.

Esses enquadramentos podem se localizar em, pelo menos, quatro lugares dentro do processo comunicacional: o comunicador, o texto, o receptor e a cultura. Um enquadramento é um trabalho organizativo e estruturante, ou seja, se constitui em mais de que um tópico dentro de um relato, uma matéria ou notícia.

Realizamos um estudo qualitativo dos enquadramentos principais presentes na MR no Brasil, baseado na análise textual ou de discurso em várias dimensóes das narrativas nas matérias. Observam-se aspectos dos estilos de representação ou "pacotes interpretativos" e definidos como ideias organizacionais centrais que moldam ou oferecem significado a um assunto (Gamson; Modigliani, 1989, p.3).

Utilizou-se a matriz elaborada pelos acadêmicos mencionados para estudar a sua interação com diferentes elementos da narrativa. Nela, foram analisados, dentro de dois grandes temas, a explicitar: a) os elementos ou dispositivos para a construção dos enquadramentos (metáforas, exemplos, ícones visuais, frases de efeito e representações); b) as categorias ou elementos de raciocínio (origens/raízes, consequências ou tipos específicos de efeitos e apelo a princípios/demandas morais), ex.: a racionalidade, a fé, as causas. No presente artigo, os ícones visuais e imagens não foram estudados de forma sistemática e trata-se predominantemente de fotos de pacientes ou gráficos de cunho científico e médico; dispositivos fora do escopo do presente trabalho.

$\mathrm{Na}$ classificação dos assuntos das matérias coletadas no presente artigo, distinguem-se apenas dois enquadramentos principais: o científico e médico - relatos que reportam conferências ou pesquisas com avanços, descobertas ou novidades - e o social - relatos que discutem controvérsias éticosociais, iniciativas de políticas públicas, aspectos econômicos e perspectivas humanistas. Dentro do último enquadramento, incluímos várias categorias secundárias de assuntos mais específicos, dependendo da sua relevância no 
conteúdo das matérias. Elas são: a ética - artigos com foco em valores morais; de política pública -, textos sobre leis, regulação; os assuntos econômico/ financeiros -, artigos sobre direitos de propriedade intelectual, custos, preços, competição e a perspectiva humanista/humanitária, que foca na narrativa de indivíduos ou grupos que podem vir a se beneficiar da MR.

Para processar a informação coletada, primeiro, os textos foram todos lidos várias vezes, classificados e codificados de forma manual e esse processo foi checado com um segundo codificador. Segundo,os tons das reportagens foram definidos, utilizando uma versão modificada das valências de Yoon (2005), e utilizada em seu estudo sobre as pesquisas com células-tronco. Cada relato foi classificado como otimista, pessimista ou neutro/descritivo. Procuraram-se palavras-chave como: sucesso, confiança, ajuda e benefício para definir os relatos otimistas; versus medo, crítica, preocupação, dúvida, risco/perigo e revés, para os pessimistas. Quando o artigo apresenta um balanço entre os atributos otimistas e pessimistas, este foi considerado como neutro ou descritivo.

Para realizar o estudo de caso, foram coletadas, entre janeiro de 2012 e maio do 2019, 39 matérias em MR nos jornais nacionais: Folha de São Paulo e O Globo, das quais foramdescartados três relatos por serem irrelevantes. A busca nos sítios dos jornais, <https://www.folha.uol.com.br/ $>$ e $<$ https:// oglobo.globo.com/>, se realizou utilizando duas palavras-chave: "terapia celular" e "terapia com células-tronco". Em um trabalho de análise de conteúdo, inédito ainda, as informações quantitativas sobre essas matérias foram analisadas; no presente artigo, fazemos referência, de modo pontual, a alguns dos dados obtidos por aquele método.

A seleção dos jornais obedece ao critério de serem os de maior circulação nacional e terem um impacto importante no Brasil. Contam com seçóes específicas e staff dedicado à publicação de relatos científicos e médicos. Os jornais de elite contribuem para o estabelecimento de uma agenda para os não de elite e costumam usar maior número de recursos e fontes. As palavras-chave e o período da amostra selecionada refletem o momento em que o campo foca-se na fase clínica em terapia celular, o estágio principal da MR também em nível global.

\section{RESULTADOS E DISCUSSÃO}

Principais enquadramentos: científico-médico e social

Analisa-se um total de 36 matérias, distribuídas dentro de dois enquadramentos principais: científico e médico (22 casos, 61\%) e social (14 casos). 
Dentro das subcategorias do social, existe uma maioria de artigos que se referem apolítica pública ( 9 em total), três são relatos econômicos e é surpreendente que, apenas umno total, apresenteuma perspectiva humanista e um outro seja de cunho ético. Isto não deixa de ser um problema: a hora de avaliar o impacto público da imprensa sobre a MR, já que pode, por um lado, diminuir a consciência pública dos debates éticos existentes e, por outro lado, limitar as identificações dos leitores com outros cidadãos.

A escassez de perspectiva humanista/humanitária nos relatos contrasta com tendências comprovadas em outros contextos da MR (Elliot, 2011) e pode vir a refletir a prioridade atribuída às informaçôes "duras" versus as "brandas" nos jornais de elite, ou seja, a respeito das dificuldades enfrentadas pelos doentes (Dawson, 2018). Mas a falta de discussão moral e ética nas matérias está de acordo com sua diminuição em nível global, uma vez que foram superadas, em muitos países, as controvérsias regulatórias em relação ao status do embrião (Kamenova; Caulfield, 2015).

\section{Dispositivos textuais utilizados nas matérias}

A seguir, exploram-se alguns exemplos dos dispositivos utilizados (metáforas, exemplos, frases de efeito e representaçôes) e se faz referência seletiva aos relatos a modo de síntese (Tabela 1). O tipo de dispositivos assinalados reflete o caráter otimista, pessimista ou neutro/descritivo de cada um dos relatos. Predomina uma avaliação otimista em mais da metade dos casos (19), enquanto os relatos se distribuem, quase por igual, entre os pessimistas e os neutros.

$\mathrm{Na}$ cobertura científica enfatizam-se os benefícios e logros versus os riscos e incertezas, com metáforas como: "chave para o mistério", "renascimento", "botão de reiniciar um computador". Ao se descrever os avanços e as descobertas científicas e médicas, utilizam-se representaçóes da terapia celular como: "muito promissora", "renova as esperanças", traz "benefícios para toda a vida”. Nas frases de efeito, recorre-se com frequência à ideia de que as novidades reparam ou interferem com "uma peça quebrada" no corpo humano ou consertam uma "perda irreparável” na saúde. A mais contundente das frases de efeito aplicadas pelos jornalistas é a que descreve as transformaçốes produzidas pela terapia celular como: "levar ao suicídio as células do câncer”, ou seja, uma extinção radical na qual as células-tronco injetadas atuam como sujeitos. 
Tabela 1:Dispositivos do enquadramento científico

\begin{tabular}{|c|c|c|c|}
\hline Metáforas & Exemplos/casos & Frases de efeito & Representações \\
\hline $\begin{array}{l}\text { Botão de reiniciar um } \\
\text { computador; loteria } \\
\text { genética; a reboque do } \\
\text { que se faz no exterior; } \\
\text { verdadeira corrida; } \\
\text { grande aposta; chave } \\
\text { para o mistério; tirar a } \\
\text { sorte; renascimento. }\end{array}$ & $\begin{array}{l}\text { Gisele, } 29 \text { anos, se } \\
\text { recupera de doença } \\
\text { de Crohn; Cathy, } 59 \\
\text { anos, tetraplégica, } \\
\text { movimenta a mão com } \\
\text { prótese de interface } \\
\text { cérebro/máquina; Elsa, } \\
58 \text { anos, se recupera de } \\
\text { incontinência urinária }\end{array}$ & $\begin{array}{l}\text { Ser irresponsável; nada } \\
\text { de excertos artificiais; } \\
\text { levar doentes à morte; } \\
\text { levar ao suicídio células } \\
\text { do câncer; não se tinha } \\
\text { mais o que oferecer; } \\
\text { nada cai do céu; a peça } \\
\text { quebrada ou que falta; } \\
\text { uma perda irreparável; } \\
\text { as incertezas persistem. }\end{array}$ & $\begin{array}{l}\text { Benefícios para toda a } \\
\text { vida; resultados muito } \\
\text { promissores; renova } \\
\text { as esperanças; mais } \\
\text { dúvidas que respostas; } \\
\text { possíveis soluções que } \\
\text { a própria natureza } \\
\text { oferece }\end{array}$ \\
\hline
\end{tabular}

Fonte: Elaboração própria

Ainda assim, muitos dos cientistas citados que manifestam um otimismo de base nas descobertas são um pouco cautelosos no uso das frases de efeito e falam de: "nada cai do céu" (em referência a quantidade de estudo e pesquisa requeridas para desenvolver as terapias celulares); salientam que, às vezes, "tem mais dúvidas de que respostas" e, o fato de que, como cientistas e médicos, devem "ser responsáveis" na forma de anunciar os avanços.

Os exemplos e casos mencionados, em geral acompanhados de material visual, são de alto impacto. Dentre eles, reporta-se o pontapé de um paciente que, usando um esqueleto biônico, abre a Copa Mundial de Futebol de 2014 no Brasil; mostra-se uma pessoa tetraplégica em cadeira de rodas que, devido às terapias aplicadas, pode movimentar uma mão; uma paciente recuperada da doença de Crohn é retratada como a "única” paciente no mundo ... Alguns dos outros textos descrevem apenas os bons resultados das primeiras fases dos ensaios clínicos em terapia celular.

Resulta interessante que, em muitas matérias, se faz referência a revistas internacionais de prestígio, como são: Nature, Science, MIT Technological Review, New England Journal of Science para valorar as novidades ou intervenções locais e não apenas como fontes parciais dos artigos. A ênfase na participação de instituições ou profissionais estrangeiros nas pesquisas ou descobertas eno fato de que algumas terapias celulares em experimentação no Brasil já foram aprovadas em países avançados são aspectos utilizados como forma de legitimação do conteúdo dos artigos.

Nos textos de predomínio científico, poucas vezes inclui-se alguma referência a aspectos políticos ou sociais. Com alguma frequência, as descobertas se apresentam como a única solução para os doentes - "não se tinha mais o que oferecer", e tentamos "tirar a sorte". Às vezes, também aparecem reflexôes e analogias em relação à ciência periférica e subordinada em um país emergente, por exemplo, "a reboque do que se faz no exterior" e "verdadeira corrida”, em referência à obtenção de dados de pesquisa e/ou a sua publicação. 
Tabela 2:Dispositivos do enquadramento social

\begin{tabular}{|c|c|c|c|}
\hline Metáforas & Exemplos/casos & Frases de efeito & Representações \\
\hline $\begin{array}{l}\text { Abre portas; seguro } \\
\text { de vida; maiores } \\
\text { patrimônios genéticos; } \\
\text { o segredo da vida; } \\
\text { brincando de criador; } \\
\text { gene com múltiplas } \\
\text { personalidades; } \\
\text { um negócio; gerar } \\
\text { desperdício; verdadeiro } \\
\text { imbróglio. }\end{array}$ & $\begin{array}{l}\text { Futebolista Neymar } \\
\text { melhora o pé com } \\
\text { injeções plasma rico } \\
\text { em plaquetas (PRP); } \\
\text { Representantes da } \\
\text { imprensa e artistas } \\
\text { famosas coletam } \\
\text { sangue do cordão } \\
\text { umbilical no parto; } \\
\text { se rejeita a Roseli, 53 } \\
\text { anos, como doadora } \\
\text { de medula óssea por } \\
\text { problemas burocráticos } \\
\text { e infraestruturais; cinco } \\
\text { mães levam filhos para } \\
\text { a cura de doenças } \\
\text { raras em um hospital } \\
\text { tailandês. }\end{array}$ & $\begin{array}{l}\text { Redução de tempos } \\
\text { regulatórios; atrair } \\
\text { investimentos } \\
\text { estrangeiros; } \\
\text { substâncias humanas } \\
\text { completamente } \\
\text { sintetizadas no } \\
\text { laboratório; células } \\
\text { humanas podem } \\
\text { salvar vidas; cautela; } \\
\text { intervenções fadadas } \\
\text { ao fracasso; lista de } \\
\text { mistérios; somos } \\
\text { voluntários e não } \\
\text { visamos o lucro; a } \\
\text { pessoa precisa saber } \\
\text { pelo que paga. }\end{array}$ & $\begin{array}{l}\text { Virou moda; resultados } \\
\text { promissores; Promessa } \\
\text { de rejuvenescimento; } \\
\text { expansão da } \\
\text { capacidade produtiva; } \\
\text { propaganda enganosa; } \\
\text { falácia pura; se a } \\
\text { comercialização } \\
\text { de células de PCTE } \\
\text { é vedada não vai } \\
\text { se investir em TC; } \\
\text { aumento na oferta. }\end{array}$ \\
\hline
\end{tabular}

Fonte: Elaboração própria

A linguagem metafórica das narrativas sociais tende a ser mais de tipo ontológico ou analógico do que no caso daquelas no enquadramento científico (Tabela 2). As descobertas descrevem-se como: estar "brincando de criador"; "gene com múltiplas personalidades" (em referência à capacidade do gene de mudar na sua expressão); revelando "o segredo da vida" ou uma novidade que "abre portas". As frases de efeito, em muitos casos, refletem preocupaçóes globais preexistentes na área da MR, por exemplo, a existência de burocracia regulatória - "redução de tempos regulatórios"- a comercialização indevida das terapias - "somos voluntários e não visamos o lucro" o risco na oferta de produtos apenas experimentais como produtos comprovados - "a pessoa precisa saber o que está pagando" e, também, a necessidade de "atrair investimentos estrangeiros" para progredir em ciência e medicina em um país emergente. Nas representaçóes das narrativas aparece a "promessa de rejuvenescimento" - um aspecto central na MR -, assim como, seu contrário: "propaganda enganosa" e "falácia pura". Os exemplos oferecidos, baseiam-se em depoimentos e fotos dos "famosos" e ocupam um lugar preponderante, por exemplo, no caso do jogador de futebol Neymar com perspectiva de cura de um pé inutilizado.

Nos relatos sociais, nota-se uma diferença com as matérias dos períodos iniciais no campo das pesquisas de células-tronco no Brasil. Naquele momento, alguns especialistas teriam achado uma propensão a reportar diferenças de opinião, em termos de "guerras" entre posiçóes contrárias (ex.: Reis, 2009; Joubert et al., 2009). Nas matérias analisadas encontram-se, apenas em três casos, referências explícitas a lutas políticas e éticas que se assumem como significativas. Elas se referem principalmente: ao contraste 
entre as posiçóes da Agência Nacional de Vigilância Sanitária (ANVISA) e dos bancos públicos, versus os argumentos dos bancos privados, para a armazenagem do sangue do cordão umbilical e da placenta.

Controvérsias político-sociais importantes são salientadas em uma grande proporção dos relatos de cunho social ( $71 \%, 10$ casos). Nesses casos, os jornalistas formulam sugestóes e críticas apenas veladas. Ainda que eles consigam reportar os dois lados das polêmicas, apresentam apenas argumentos parciais. Por exemplo, isso acontece na formulação de críticas à lentidão nas aprovações éticas, das demoras nos ensaios clínicos devido a um excesso de burocracia e da regulação insatisfatória na aprovação regulatória de vários tipos de clínicas e atividades científicas.

Em concordância com os resultados obtidos em estudos desenvolvidos em países avançados, os jornalistas locais parecem muito atraídos por focar ou desenvolver controvérsias (ex.: Haran; Kitzinger, 2009). Ainda assim, isto acontece apenas nos artigos de cunho social. Nas matérias científicas, desenvolvem-se poucos relatos que apresentem debates frequentes em nível global, por exemplo, entre tipos de células-tronco utilizáveis para algumas pesquisas (ex.: células de pluripotência induzida - iPS - versus células-tronco embrionárias - CTE) ou sobre decisões médicas entre aplicar um tratamento celular ou manter o convencional.

O uso de exemplos costuma ser mais extenso nas matérias de cunho social do que nas científicas e médicas. Nos depoimentos pessoais ou nas citaçóes destes, intenta-se familiarizar os leitores com o estado atual da situação. Descrevem-se principalmente os processos de pacientes que passaram por intervenções em terapia celular e foram bem sucedidos ou que começam a ter esperanças de cura com essas terapias, assim como as mudanças nas opiniôes de indivíduos renomeados ao conhecerem resultados positivos das novas aplicações.

No enquadramento social, em especial, as narrativas sugerem grandes diferenças nas formas em que os cientistas e os jornalistas descrevem os novos desenvolvimentos na área. Os jornalistas utilizam tons mais otimistas e frases como: "câmbio profundo", "renova as esperanças"; enquanto os cientistas são cautelosos em descrever o progresso científico e médico e incluem expressóes como: "nada é milagroso"; deve-se "ficar perto da realidade"; e ainda "há muito a ser avaliado".

Ainda assim, os cientistas tendem a ser ambíguos ou inespecíficos ao estipular o momento em que as terapias serão comprovadas. Em geral, utilizam frases como: "a curto prazo", "logo", "em um tempo breve", "em certo tempo"; e em poucos artigos se explicita um período de tempo aproximado para a sua entrada no mercado, ex.: "de 5 a 10 anos" ou "em quase 
15 anos”. Até um certo ponto, parece se ter superado as promessas de cura muito exageradas ('bype') e que predominava nas últimas duas décadas na reportagem na área (ex.: Brown, 2003; Acero 2010; 2011). Mas existe ainda uma predição otimista demais no relato dos jornalistas e, em parte, como consequência dos tempos indeterminados informados pelos cientistas para que suas descobertas se transformem em produtos. Isto pode vir a induzir ainda um certo nível de falsas expectativas nos leitores.

\section{Elementos do raciocínio nas matérias}

O raciocínio nas matérias como um todo apela principalmente à racionalidade científica, ao progresso e ao desenvolvimento tecnológico, em especial, em relação aos avanços da MR no país. Um apelo secundário, do tipo causa/ efeito, aponta para aresolução do sofrimento humano, ou seja, aceitar a sua existência e tentar transformá-lo. Os apelos éticos ou morais encontrados nas matérias são muito limitados.

A seguir, apresentam-se trechos comentados das notícias na Folha de São Paulo, para revelar os elementos de raciocínio presentes nos relatos. Escolheu-se ilustrar o assunto com notícias apenas desse jornal, porque nelas aparecem os elementos analisados de forma mais sistemática e esclarecedora.

Com respeito ao apelo à racionalidade científica, uma resenha de 6 de abril 2018, manifesta uma relativa cautela ao descrever uma pesquisa sobre a criação de ossos e cartilagem "à la carte”:

"O procedimento desenvolvido pela Bônus, ainda em testes, envolve o cultivo de tecido ósseo vivo sob medida a partir de células-tronco retiradas da gordura do próprio paciente com lipoaspiração - ou seja, nada de enxertos artificiais. A tecnologia poderá permitir que qualquer pessoa encomende o osso de que necessita em caso de trauma, infecção ou câncer, por exemplo. (...) Com relação aos experimentos $\mathrm{da}$ área de engenharia de tecidos, os pesquisadores alertam que é importante ter cautela. 'A validação desse tipo de pesquisa é muito importante. Não se pode correr com os testes clínicos” ( ênfase própria).

Observa-se que o otimismo manifestado pelo jornalista de que qualquer um possa vir a receber este tipo de tratamento contrasta com a retórica mais cautelosa do cientista citado. Em contraste, o princípio pelo qual o jornalista julga a descoberta e as suas consequências, parece responder a uma lógica universalista.

Em relação ao apelo ao desenvolvimento tecnológico no país, uma matéria do 23 de janeiro de 2019, intitulada: "Governo de SP estuda parceria entre Butantan, USP e farmacêutica Novartis”, especificaque a empresa investiu 150 milhões em pesquisa no país nos últimos três anos. $\mathrm{O}$ artigo comenta um 
encontro do então prefeito de São Paulo, João Dória, com o Presidente do Instituto Novartis de Pesquisa Biomédica, James Bradner:

“O objetivo declarado de Dória em Davos é atrair investimentos estrangeiros para São Paulo. Uma das metas é formar parcerias com o setor privado para que o Butantan se torne o maior produtor mundial de vacinas. A Novartis recentemente vendeu sua área de vacinas para GSK, com a qual o Butantan também tem uma parceria” (ênfase própria).

Essa matéria não deixa de ser presunçosa em relação aos efeitos potenciais, para o futuro do Brasil, do investimento obtido para a produção de vacinas; estabelecem-se metas irrealistas que apelam à identidade e ao orgulho nacional. A notícia é apenas uma entre $52,7 \%$ de artigos ( 19 em total) sobre parcerias estratégicas público/privadas na $\mathrm{MR}$; uma estratégia governamental de promoção em saúde instalada nos anos 2000 (Barbosa; Malik, 2015).

Outro texto, de 11 de setembro de 2018, salienta os obstáculos regulatórios existentes para o desenvolvimento de terapias celulares, segundo são reportados por um gerente de uma empresa que pretende investir no Brasil:

"Há uma busca da ANVISA [Agência Nacional de Vigilância Sanitária] por redução de tempos regulatórios, mas ainda temos uma espera maior que em outros lugares”, diz ele (...) 'O intervalo para aprovação de um ensaio clínico, que já foi de dois anos, costuma chegar a um ano atualmente', afirma Gibim. (...) 'Poderíamos ter mais [pesquisas locais] se se operasse mais próximo da realidade europeia, com um prazo de 4 a 5 meses.' (...) Aportes em expansão de capacidade produtiva, porém, estão descartados. 'Nossa presença industrial no Brasil é adequada com a visão de pelo menos 4 a 5 anos no país', afirma o executivo" (ênfase própria).

O relato tem uma motivação subjacente de propor flexibilidade regulatória, uma crítica velada à ineficiência do sistema atual e, indiretamente, uma promessa de maior investimento no Brasil, se as condiçóes regulatórias fossem tão promissoras quanto na Europa. Explicita-se também um tempo limitado de investimento, condicionado à possível transformação regulatória.

$\mathrm{O}$ apelo à causa/efeito em respeito ao sofrimento dos pacientes, pode se exemplificar no seguinte trecho de uma matéria do 6 de abril de 2018, sobre novas técnicas com células-tronco para a regeneração de cartilagem:

"Foram dois procedimentos cirúrgicos, muitas sessóes de fisioterapia e horas de musculação. $O$ tamanho da cicatriz no joelho direito -25 pontos no total - não é maior que o alívio.(...) 'Por enquanto não posso correr nem fazer agachamentos, mas estou sem dor, restabelecendo uma vida normal'”, diz Paula (ênfase própria). 
Este constitui um caso bem esclarecedor do uso da inovação para a melhora da qualidade de vida versus a cura, no qual se têm focado muitos dos tratamentos com terapia celular em nível global (Kaminova; Caulfield, 2015). Ainda assim, a narrativa prioriza os efeitos positivos do tratamento sobre os negativos.

Outro exemplo baseado em uma perspectiva humanitária relata-se no caso de uma paciente com a doença intestinal de Crohn, em uma matéria de 15 de maio de 2014:

"Um procedimento similar ao transplante de medula óssea para tratamento de linfoma conseguiu pela primeira vez no Brasil salvar uma paciente com doença de Crohn, transtorno autoimune que causa inflamação intestinal (...). O método, tecnicamente um transplante de células-tronco sanguíneas, ainda não foi aprovado por autoridades regulatórias brasileiras.Apesar disso, já está sendo usado para casos mais graves da doença em hospitais nos Estados Unidos e Europa (...) Antes de ser submetida ao transplante em outubro do ano passado, [a paciente] situava-se entre os casos mais graves de Crohn.' Tive que parar de trabalhar, parar a faculdade, parar tudo', conta. 'Precisava de ajuda em casa até para pentear o cabelo e tomar banho, porque não tinha mais força"” (ênfase própria).

Manifesta-se de modo explícito um princípio moral humanista, já que o tratamento acontece ainda que não tenha sido aprovado como ensaio clínico no Brasil. A terapia se legitima na experiência internacional e é aplicada com base na gravidade do caso e na falta de soluçôes alternativas ou que tenham funcionado de modo prévio. Esse trecho ilustra a tendência global atual à aplicação de flexibilidades regulatórias na MR (Acero, 2019).

O apelo ético, que não é muito presente nos relatos, reflete-se em um artigo de 2 de agosto de 2017, em relação à edição de genes pela técnica CRISPR-Cas9 - bastante controvertida em nível global (ex. Ledford, 2015). Explicam-se duas posiçôes antitéticas habituais:

"Em dezembro de 2015, um grupo internacional de cientistas e especialistas em ética convocados pela Academia Nacional de Ciências Americana (NAS) em Washington considerou que seria 'irresponsável' utilizar a tecnologia CRISPR para modificar o embrião com fins terapêuticos até que as questões legais, de segurança e de ética não fossem resolvidas. (...) Mas em março de 2017, a NAS e a Academia de Medicina americana consideraram que os avanços realizados na técnica de edição genética das células humanas de reprodução 'abrem possibilidades realistas que merecem sérias consideraçóes'.” (ênfase próprio).

A mudança nas recomendações de associações científicas respeitadas em nível global é percebida como exclusivamente ligada ao avanço na tecnologia mencionada. Ainda mais, as consequências de seu uso apelam, em grande 
medida, a um princípio ético ambíguo: deixar "em aberto" a opção - a aplicação ou não da técnica - até novas considerações dos riscos e incertezas em vez, por exemplo, de sugerir o uso do princípio de precaução.

\section{CONCLUSÃO}

Além da situação descrita do jornalismo científico no contexto internacional e a suapotencial influência no Brasil, a análise das matérias selecionadas apresenta tendências semelhantes às coberturas da MR na imprensa internacional, como: a presença de imaginários sociais de futuros muito promissores, a indeterminação dos tempos de aprovação e inclusão das TC nos sistemas de saúde pública e no mercado e/ou estimativas baseadas em uma rapidez exagerada, um sentido do progresso científico de tipo lineare que pode influirna formação de novas identidades mais adequadas à modernidade, assim como a escassez de matérias sociais, políticas e legais nas coberturas.

Mas também a coberturareflete algumas características culturais locais nas experiências, afetos e sentidos transmitidos - como é o sentido comunitário e compassivo salientado em alguns dos relatos, uma visão baseada mais na segurança que nas incertezas das técnicas, e o orgulho nacional nas descobertas - assim como, o caráter subordinado do jornalismo científico em um país emergente. Evidencia-se, por exemplo, a grande diferença entre a linguagem dos jornalistas e dos cientistas locais sobre as descobertas e na forma de salientar e avaliar os temas, assim como a imprecisão na narrativa jornalística e o escasso escrutínio da veracidade e validade dos dados. As condições em geral mais adversas desta profissão no Brasil, comparadas com a dos países avançados, também podem influir nesses descuidos nos relatos, o quepode constituir-se em um tema de futuras pesquisas.

Os resultados obtidos revelam uma qualidade deficiente e incompleta da informação da MR na imprensa, com bastantes vieses e dependente de fontes internacionais para a sua legitimação. $\mathrm{O}$ total das matérias em $\mathrm{MR}$, no período recente, resulta surpreendentemente escasso, em especial, se leva-se em conta que ela constitui uma área de ponta em nível nacional e global. Os assuntos científicos e médicos dominam o panorama textual e refletem a ideia de progresso, novidade e o entusiasmo dos jornalistas e na comunidade científica e médica sobre a experimentação com terapia celular. Ainda assim, o informe sobre as datas para o desenvolvimento das terapias como produtos aparece inespecífico. 
Nesse sentido, os relatos produzidos pelos jornalistas são otimistas demais a respeito do triunfo e dos logros das descobertas médicas e pouco discutemse os riscos e as incertezas científicas nesta etapa que, em nível global, são ainda apontados como significativos (ex. Ruhrmann, 2015). Tudo isto, pode vir a contribuir na formação de expectativas exageradas ou falsas no público, ainda que possivelmente em menor medida que em décadas passadas. De fato, cientistas brasileiros entrevistados na área na nossa pesquisa atual queixamse em reiteradas oportunidades do número de pessoas, desesperadas e/oumal informadas, que os procuram no cotidiano e demandam aplicaçôes terapêuticas de técnicas que ainda encontram-se em fase de pesquisa pré-clínica.

Os dispositivos usados pela imprensa nas notícias científicas e sociais são bem diferentes. Nos relatos sociais predominam as controvérsias, mas elas são mais sugeridas do que abordadas de modo sistemático e refletem imprecisão e pouca validação das fontes utilizadas. Estas matérias constituem as mais amplamente ilustradas por casos e exemplos de pacientes em cura, esperançosos e/ou famosos. Recorre-se ao uso de metáforas de cunho ontológico e frases de efeito que aludem bastante a aspectos regulatórios não solucionados e alertam ao público, de um modo relativo, sobre o lucro potencial nas terapias.

A imprensa local na MR não parece contribuir a democratização do conhecimento científico e médico de modo que ajude na formulação de um panorama abrangente e uma avaliação crítica por parte dos cidadãos, para que eles possam exercer adequadamente seus direitos à saúde nesta nova área de prática. A quase ausência de debate ético e sociopolítico nas matérias e a inclusão de fontes muito seletivas limitam o escopo do entendimento público e das escolhas possíveis na saúde no presente e no futuro próximo.

As interpretaçóes nas matérias apresentam um raciocínio que apela principalmente à racionalidade científica e ao progresso de modo linear, da MR no Brasil e desde uma perspectiva universalista e que, com frequência, gaba-se da identidade nacional. A comunicação nos relatos tem um caráter pouco dialógico com grupos e associaçóes relevantes da sociedade civil. As fontes priorizadas e os estilos representacionais dos relatos alinham a comunicação pública da imprensa com a abordagem teórica 'top down' do entendimento público da ciência. Apela-se nos textos, apenas de forma secundária à saúde coletiva e as experiências dos doentes.

O método construtivista adotado na análise - baseado na construção de sentido dentro do processo de comunicação em ciência e na matriz metodológica de Gamson, Modigliani (1989) - permite revelar os padróes interpre- 
tativos persistentes observáveis nos relatos sobre a MR, ao contribuir com uma forma de acessar os processos de pensamento envolvidos e as experiências que pretendem-se transmitir ao público. Apenas por se utilizar métodos interpretativos, pode-se avaliar a articulação dos diferentes pacotes mediáticos nas atribuições de sentido e significado que o público realiza sobre os assuntos científicos e da saúde. Deste modo, eles resultam úteis para pesquisar sua integração nas epistemologias cívicas e no modo como se constrói o entendimento público da ciência e a saúde em um país emergente.

\section{AGRADECIMENTOS}

Agradeço a contribuição da doutoranda e orientanda Bruna Castanheiras na coleta e codificação inicial das matérias analisadas e às Prof. Maria Tereza Leopardi Mello e Ana Célia Castro pelo seu apoio em tanto Coordenadora e Vice-coordenadora do Programa de Pósgraduação em Políticas Públicas, Estratégias e Desenvolvimento (PPED), do Instituto de Economia (IE), da Universidade Federal de Rio de Janeiro (UFRJ) onde atuo como Professora Visitante Estrangeira Senior.

\section{Referências}

ACERO, L. Science, public policy and engagement: Debates on stem cell research in Brazil. Life Sciences and Social Policy, v.6, n. 3, p.1-17, 2010.

ACERO, L. Pesquisas e Terapias com CélulasTronco: Visões Sociais e o Debate no Brasil 2011. Rio de Janeiro: E-Papers.

ACERO, L. Regulação internacional e governança na medicina regenerativa: trajetórias do Reino Unido e a União Europeia e repercussões para a saúde coletiva global. OIKOS, v. 18, n. 2, p. 82-95, 2019.

ASWELL, DJ. The challenges of science journalism: The perspectives of scientists, science communication advisors and journalists from New Zealand. Public Understanding of Science, v. 25, n. 1, p. 379-393, 2016.

BARBOSA , A. ; MALIK,A. Desafios na organização de parcerias público-privadas em saúde no Brasil. Análise de projetos estruturados entre janeiro de 2010 e março de 2014. Revista de Administração Pública, v. 49 n.5 Rio de Janeiro, 2015.

BAUER, M. W.; HOWARD S.; YULVE, J.; RAMOS R., MASSARANI L. , AMORIN L. Global sciencejournalismreport: workingconditions\&practices, professional ethosand future expectations. Ourlearning series. London: Science andDevelopment Network, London SchoolofEconomicsandPolitical Science, 2013.

BESLEY, JC.; TANNER, AH. Whatscience communication scholars thinkabout training scientiststocommunicate.Science Communication,v. 33, n. 1, p. 239-263, 2011.

BROWN, N. Hope against hype Accountability in biopasts. Presentsand Futures, ScienceStudies, v. 16, n. 2, p. 3-21, 2003.

BRUMFIELD, G. Science journalism: Supplantingtheold media? Nature,v.458, p. 274-277, 2009.

BULLOCK, O., AMILL, D., SHULLMAN, H., DIXON, G. Jargon as a barrier to effective science communication: Evidence from metacognition. Public Undersandingof Science, v. 28, n.7, p. 845-853, 2019.

CASTELL, S.; CHARLTON, A, Clemence, M, Pettigrew, N, Pope, S, Quigley, A. Public Attitudes toScience. London: Department for Business, Innovationand Skills, 2014.

CHYI, HI.; LEWIS, SC; ZHENG,

$\mathrm{N}$. A matter of life and death? 


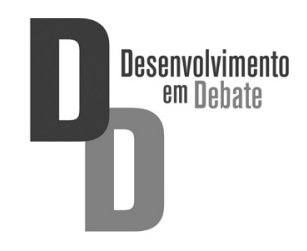





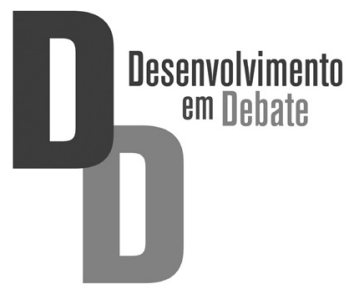

\section{POLITTICA EDITORIAL}

A equipe editorial da revista Desenvolvimento em Debate se compromete a manter elevada conduta ética durante todo o processo em relação à publicação e seus colaboradores; rigor com a qualidade dos artigos científicos a serem publicados; selecionar revisores capacitados e ecléticos com educação ética e respeito profissional aos autores e ser imparcial nos processos decisórios, procurando fazer críticas sempre construtivas e profissionais. Para tal fim, a revista adota o código de conduta do Conselho Nacional de Desenvolvimento Científico e Tecnológico (http://www.cnpq.br/web/guest/diretrizes).

A revista publica artigos originais de pesquisa, ensaios e resenhas relacionados com a temática do desenvolvimento socioeconômico. Ênfase é dada a trabalhos que analizam o papel do Estado e das instituiçóes no desenvolvimento, políticas públicas setoriais e estratégias de desenvolvimento, o papel da geopolítica na dinâmica econômica e sustentabilidade ambiental, como também a pesquisas acerca de casos nacionais ou em perspectiva comparada, sobretudo de países da América Latina.

Os textos submetidos para publicação podem ser em português, espanhol ou inglês e devem ser inéditos. Ocasionalmente, por seu mérito acadêmico, a revista publica traduzóes de artigos originais em linguas que não sejam o português.

Pelo menos um dos autores deve ter a titulação mínima de mestre.

A revista adota o processo de avaliação por pareceristas anônimos. Os artigos passam por um processo de avaliação com três etapas. Na primeira, de caráter formal, avalia se o texto respeita as normas editoriais. $\mathrm{Na}$ segunda, decide se o artigo se adequa ou não ao escopo da Desenvolvimento em Debate. Em caso de ser negativo, comunica aos autores o motivo da rejeição. Em caso de ser positivo, o artigo é enviado a pareceristas externos. A publicação está condicionada à aprovação por parte de dois avaliadores externos à revista. 
O corpo editorial pode aceitar artigos para publicação, com ou sem recomendação de alteraçôes. Nõ caso de serem necesárias alterações, a versão final do artigo deve ser enviada no prazo de um mês posterior ao envio da avaliação dos pareceristas externos.

\section{NORMAS PARA A SUBMISSÃO DE ARTIGOS}

- Os artigos devem ser submetidos pelo correio eletrônico da revista: revdesenvolvimentoemdebate@gmail.com.

- Os artigos submetidos devem ter entre 7,000 e 12,000 palavras (incluindo as notas de fim, resumos, bibliografia e legendas), em fonte Times New Roman, tamanho 12, com espaço 1,5 e parágrafo justificado.

- Os manuscritos devem incluir um resumo em português e em inglês, explicitando objetivos do artigo, metodologia epregado e as principais conclusóes. O resumo deve ter entre 100 e 150 palavras e deve ser acompanhado de entre 3 a 5 palavras-chave.

- Devem ser submetidos no mesmo processo dois arquivos. Um contendo os dados dos autores e outro com o manuscrito sem identificação de modo de evitar qualquer informação que revele a autoria do artigo.

- As notas de fim deverão ser evitadas ao máximo e, quando existirem, restringirem-se a conteúdo e estarem enumeradas automaticamente em algarismos arábicos em ordem crescente e listadas no final do texto.

- As citações diretas com mais de três linhas devem estar destacadas do texto, recuadas $4 \mathrm{~cm}$ à esquerda e com espaçamento simples entre linhas. O texto deverá ser digitado em Word For Windows e não deverá ter numeração de páginas.

- As figuras devem incluir um título auto-explicativo, na língua do texto, numerado em algarismo arábico, alinhado na margem esquerda e posicionado logo acima da figura. A fonte deve estar logo abaixo da figura. Aqui incluem-se, gráficos, fotografias (nítidas e com contraste), desenhos, etc.

- As tabelas dvem suplementar e não duplicar o texto, numeradas em algarismos arábicos. O título deve ser auto-explicativo, na língua do texto, alinhado na margem esquerda e posicionado acima da tabela. A fonte deve estar logo abaixo da tabela. 
As Referências Bibliográficas no texto devem ser citadas de forma corrida, segundo as normas da ABNT. Recomenda-se evitar citação de resumos simples, somente citando resumos expandidos de Congressos ou de outro evento científico de mesma natureza.

\section{LISTA DE REFERÊNCIAS}

Toda a literatura citada ou indicada no texto deverá ser listada em ordem alfabética. Artigos em preparação ou submetidos à avaliação não deverão ser incluídos nas referências. A formatação das referências deve seguir o padrão estabelecido pela Associação Brasileira de Normas Técnicas (ABNT) em "Regras Gerais de Apresentação" - NBR-6023, de agosto, 2002.

\section{Exemplos de referências}

Os exemplos a seguir não devem ser considerados como referências reais, pois alguns tiveram elementos adicionados a título de exemplificação.

\section{Livros}

SOBRENOME, Inicial nome. Título. Cidade da editora: Editora, Ano de publicação.

\section{Exemplo:}

REID, D. Sustainable development: an introductory guide. 1. ed. London: Earthscan, 1995.

\section{Capítulos de livro}

SOBRENOME, Inicial do nome. Título. In: SOBRENOME do ORGAZINADOR, Inicial do nome (Org.). Título da obra. Cidade da editora: Editora, Ano de publicação, páginas.

Exemplo:

ALMEIDA, L. T. Comércio e meio ambiente nas negociações multilaterais. In: BRAGA, A. S.; MIRANDA, L. C. (Org.). Comércio e meio ambiente: uma agenda positiva para o desenvolvimento sustentável. Brasília: MMA/SDS, 2002. p. 97-134.

\section{Artigos em periódicos}

SOBRENOME do autor, Inicial. Título do artigo. Título da revista, volume, número, páginas do artigo, ano de publicação.

Exemplo:

ANYANWU, C. N. The technique of participatory research in community development. The Community Development Journal, v. 23, n. 4, p. 11-15, 1988. 


\section{Trabalho apresentado em evento}

SOBRENOME do autor, Inicial do nome. Título. In: EVENTO, Ano do evento, Cidade do Evento. Anais, página. Disponível em: <hiperlink $>$. Acceso em: data (formato Dia, mês, ano).

Exemplos:

SOUZA, L. S.; BORGES, A. L.; REZENDE, J. O. Influência da correção e do preparo do solo sobre algumas propriedades químicas do solo cultivado com bananeiras. In: REUNIÃO BRASILEIRA DE FERTILIDADE DO SOLO E NUTRIÇÃO DE PLANTAS, 21., 1994, Petrolina. Anais... Petrolina: EMBRAPA, CPATSA, 1994. p. 3-4.

ANDRADE, T. Inovação tecnológica e meio ambiente: dando um passo acima. In: ENCONTRO DA ASSOCIAÇÃO NACIONAL DE PÓS GRADUAÇÃO E PESQUISA EM AMBIENTE E SOCIEDADE, 2., 2004, Indaiatuba, SP. Anais... Indaiatuba: ANPPAS 1 CD-ROM.

ANDRADE, T. Inovação tecnológica e meio ambiente: dando um passo acima. In: ENCONTRO DA ASSOCIAÇÃO NACIONAL DE PÓS GRADUAÇÃO E PESQUISA EM AMBIENTE E SOCIEDADE, 2., 2004, , Indaiatuba, SP. Anais... Indaiatuba: ANPPAS 2004. Disponível em: <http://www.anppas.org.br/encontro_anual/encontro2/GT/GT01/thales. pdf >. Acesso em: 31 ago. 2007.

\section{Dissertações, teses e relatórios}

SOBRENOME, Inicial do nome. Título. Ano, Número de páginas. Dissertação - Centro, Universidade, Cidade.

Exemplo:

SERRANO, C. M. T. A invenção do Itatiaia. 1993. 179 f. Dissertação (Mestrado em Sociologia) - Instituto de Filosofia e Ciências Humanas, UNICAMP, Campinas.

\section{Trabalhos em meio-eletrônico}

Exemplo:

SÃO PAULO (Estado). Secretaria do Meio Ambiente. Tratados e organizações ambientais em matéria de meio ambiente. In: . Entendendo o meio ambiente. São Paulo, 1999. v. 1. Disponível em: <http:://www.bdt.org. br/sma/entendendo/atual.htm>. Acesso em: 8 mar. 1999.

\section{Artigos de periódico em meio eletrônico}

Exemplos:

AIKAWA, N. Visión Histórica de la Preparación de la Convención Internacional de la UNESCO para la Salvaguardia del Patrimonio Cultural Inmaterial. Museum Internacional. Patrimonio Inmaterial. Paris, UNESCO, 
n. 221-222, p. 140-155, 2003. Disponível em: <http://portal.unesco.org/ culture/en/ev.php>. Acesso em: 5 set. 2006.

JOLY, C. A. Acesso a recursos genéticos, repartição de benefícios e proteção dos conhecimentos tradicionais. Biota Neotrop., v. 5, n. 1, p. 3-3, 2005. Acesso em: 26 jun. 2006. Disponível em: <http://www.scielo.br/scielo. php?script $=$ sci_arttext $\&$ pid $=$ S1676=06032005000100001-\&lng=en\&nrmiso $>$.

ISSN 1676-0603. online.

Legislação BRASIL - SNUC. Lei no 9.985 de 18 de julho de 2000. Institui o Sistema Nacional de Unidades de Conservação e dá outras providências. Brasília, DF, 2000.

O envio espontâneo de qualquer colaboração implica automaticamente a cessão integral dos direitos autorais ao INCT-PPED. A revista não se obriga a devolver os originais das colaborações enviadas. 
Desenvolvimento em Debate 